At-Tijaroh: Jurnal Ilmu Manajemen dan Bisnis Islam

Volume 7 (2), 2021: 186 - 195

P-ISSN: 2356-492X; E-ISSN: 2549-9270

\title{
THE METHOD OF EMPOWERMENT SOUL ENTREPRENEURSHIP OF YATIM AND DHUAFA ORPHANAGE HAFIZIL YATAMU SABUNGAN JAE
}

\author{
Windari ${ }^{1}$, Damri Batubara ${ }^{2}$
}

windari@iain-padangsidimpuan.ac.id ${ }^{1}$, damri.batubara1234@gmail.com ${ }^{2}$

\begin{abstract}
This Yatamu Hafizil Orphanage is a social foundation that educates and fosters entrepreneurial skills for orphans and poor people with social problems. Like economic capacity, left behind by dead father and mother. The theory explains, financial, entrepreneurial spirit, thinking, creative spirit, innovative are the core requirements for empowering the entrepreneurial spirit. Unlike the orphanage and poor people in Sabungan Jae accepts children to be empowered for their entrepreneurial spirit at no cost. This is contrary to the requirements for empowering an entrepreneurial spirit. entrepreneurship requires sufficient capital, a strong physical condition, has a creative and innovative mindset. This research is a descriptive qualitative research. The data sources used are primary and secondary. The informant retrieval method used was purposive sampling, while the data collection techniques were observation, interview and documentation. The instrument used in the interview was a focus group discussion. The analysis of the validity of the data used was source triangulation. As a result, there are several methods of empowering the entrepreneurial spirit of the orphanage and poor people. Namely, snowballing lessons, meet the guests, town meetings, whatsapp conferences.
\end{abstract}

Keywords: empowerment, entrepreneurship, orphans and poor people

Received: September 28 ${ }^{\text {nd }}$, 2020; Revised: April 20"th 2021; Accepted: Nopember 22 ${ }^{\text {nd }}, 2021$

Institut Agama Islam Negeri Padangsidimpuan and Jl. T. Rizal Nurdin Km. 4,5 Sihitang

E-mail: windari@iain-padangsidimpuan.ac.id ${ }^{1}$, damri.batubara1234@gmail.com $^{2}$

DOI: https://doi.org/10.24952/tijaroh.v6i2.2453 


\section{Introduction}

Foundation the Hafizil Yatamu orphanage is a social institution founded by Muhammad Jamil Rasyid Pisang in 1996. Then continued by Ustz Ahmad Yunus Hasibuan with his wife Yusra Kadira after its founder died in 2005. The hafizil yatamu orphanage is a social foundation that educates and fosters entrepreneurial skills of orphans and poor people who have social problems such as economic ability, are left behind by their father, mother or both. Even close family cannot provide welfare, comfort and do not have a clear future (Ana Toni Roby Candra Yudha 2016).

Through this Hafizil Yatamu orphanage foundation, orphans and poor people are educated and fostered their entrepreneurial spirit so that they can restore their confidence and have a clear future. In accordance with the mandate of Law no. 4 of 1974 concerning child welfare. This legal product guarantees the realization of children's welfare through the fulfillment of children's basic needs, proper growth and development both spiritually, physically and socially. Likewise regulating the responsibilities of parents for the welfare of children including, welfare rights, services, maintenance and efforts for child welfare, development, prevention and rehabilitation (Undangundang Republik Indonesia 1979).

In Law no. 23 of 2002 concerning child protection. Every child has the right to obtain health services, social security in accordance with their physical, mental, spiritual and social needs. Also entitled to education and teaching in terms of personal development and level of intelligence according to their interests and talents (Undang-Undang Republik Indonesia 2002).

Being an interesting thing, in theory, it is explained that empowering the entrepreneurial spirit is not as easy as turning a hand or tangible capital, but requires a lot of certain conditions that must be met (kasdi dan moerdiyanto 2017). One of them is that there must be entrepreneurial spirit (proportional quality) for the business actor (Yuyus Suryana 2014). Have thinking capital and creative spirit (create new and different), innovative (Yuyus Suryana 2014), and organized organization (George R Terry 2000), without these conditions empowering the entrepreneurial spirit is a futile endeavor. As in conventional theory, capital is one of the cores in building entrepreneurship. Many entrepreneurs prioritize capital / financial (tangible), but there is no entrepreneurial spirit (proportional quality). Finally, their business is only as long as corn. When the business capital has run out, there is no ability to develop the business anymore. So financial and entrepreneurial spirit are the two core assets in entrepreneurial empowerment.

It is different from the empowerment of the entrepreneurial spirit in the hafizil yatamu orphanage sabungan jae padangsidimpuan. This orphanage accepts orphans and dhuafa to nurture 


\section{Windari, Damri Batubara}

The Method of Empowerment Soul Entrepreneurship of Yatim and Dhuafa Orphanage Hafizil Yatamu Sabungan Jae

and develop their entrepreneurial spirit without being charged the slightest fee, of course, the majority of these children are poor people (pakir). This situation is contrary to the requirements for entrepreneurial empowerment, to empower the entrepreneurial spirit, sufficient capital is needed. Likewise, the physical condition of the orphanage children who are still unstable, of course will affect creative and innovative thinking patterns which are the core requirements in entrepreneurship. But conditions like this do not affect the empowerment of the entrepreneurial spirit of the hafizil yatamu orphanage sabungan jae padangsidimpuan. It is proven that there have been many regeneration of these orphanages that have developed and become entrepreneurs at the district, provincial, national and international levels. For example, someone opened a photo copy shop in Padangsidimpuan, a restaurant merchant in Batam, a flower trader in Palembang, there was even a restaurant merchant in Taiwan and 16 people who worked in national industries in Indonesia (Ahmad Yunus Hasibuan 2020).

Therefore, it is necessary to know how the method used by the orphanage is in empowering the entrepreneurial spirit of orphans and poor people in the hafizil yatamu orphanage, Sabungan jae, Padangsidimpuan city.

\section{Methods}

Based on the data in the introduction, this research is a qualitative research with a descriptive approach without using numbers or statistics. The author will explore a single entity or phenomenon, reality, symptoms that occur in the hafizil yatamu orphanage sabungan jae padangsidimpuan on methods of empowering the entrepreneurial spirit of orphans and dhuafa. The author will describe the phenomena or experiences they have carried out in fostering the entrepreneurial spirit of the orphanage children without using capital.

Sources of data used in this study are primary data sources, namely data obtained directly from the informant owner of the hafizil yatamu orphanage foundation jae padangsidimpuan and all the elements involved in nurturing and fostering the entrepreneurial spirit of the orphans and poor people. The informant retrieval technique used is purpose sampling, namely, by determining the consideration that the informant is considered to know the best and is directly involved in educating and empowering entrepreneurial children of the hafizil yatamu orphanage sabungan jae padangsidimpuan. 
Furthermore, using secondary data, namely additional data and supporting primary data, which the author obtained through library research by reading books, journals and documents related to research.

While the data collection techniques used were interviews, observation and documentation study. Based on the research focus, the instruments used were interview guidelines, focus group discussions, observation guidelines, and the researchers themselves who conducted the interviews (Sugiyoni 2017).

The data validity analysis used was source triangulation, namely testing the credibility, transferability, dependability, and confirmability of the data to several sources, this could make it easier for researchers to check the credibility of the data (Sugiyono 2016).

The data analysis technique used is interactive analysis through data collection, data reduction, data display, drawing conclusions and preparation of recommendations (Sugiyono 2016).

\section{Result And Discussion}

Based on the results of an interview with Ustz Ahmad Yunus Hasibuan, the chairman of the hafizil yatamu orphanage foundation, jae padangsidimpuan and also the coaches and carers of the orphanage (Ahmad Yunus Hasibuan 2020).

There are several methods applied in educating and fostering orphans and poor people at the Hafizil Yatamu orphanage. The method applied varies depending on the class it is in. Because there are several class divisions established by the foundation in educating and fostering these orphans and dhuafa. So the first attempt made to differentiate the classes first identifies the psychology of the child in depth, both in terms of character, character and talents, after studying it for a long time. Because not all children who enter the orphanage have the same physiology, both in terms of character, character, and talents.

Then classify their respective areas of ability without distinguishing their age and sex. After the orphans and the poor have classified the areas of ability of each, only then are the educators and coaches of their respective classes determined according to their expertise. This method is done so that it is easy to organize and easy to open the mindset of creativity and innovation of the child. 


\section{Windari, Damri Batubara}

The Method of Empowerment Soul Entrepreneurship of Yatim and Dhuafa Orphanage Hafizil Yatamu Sabungan Jae

The proficiency classes defined by the Hafizil Yatamu Orphanage Foundation Sabungan Jae Padangsidimpuan can be seen in the picture below.

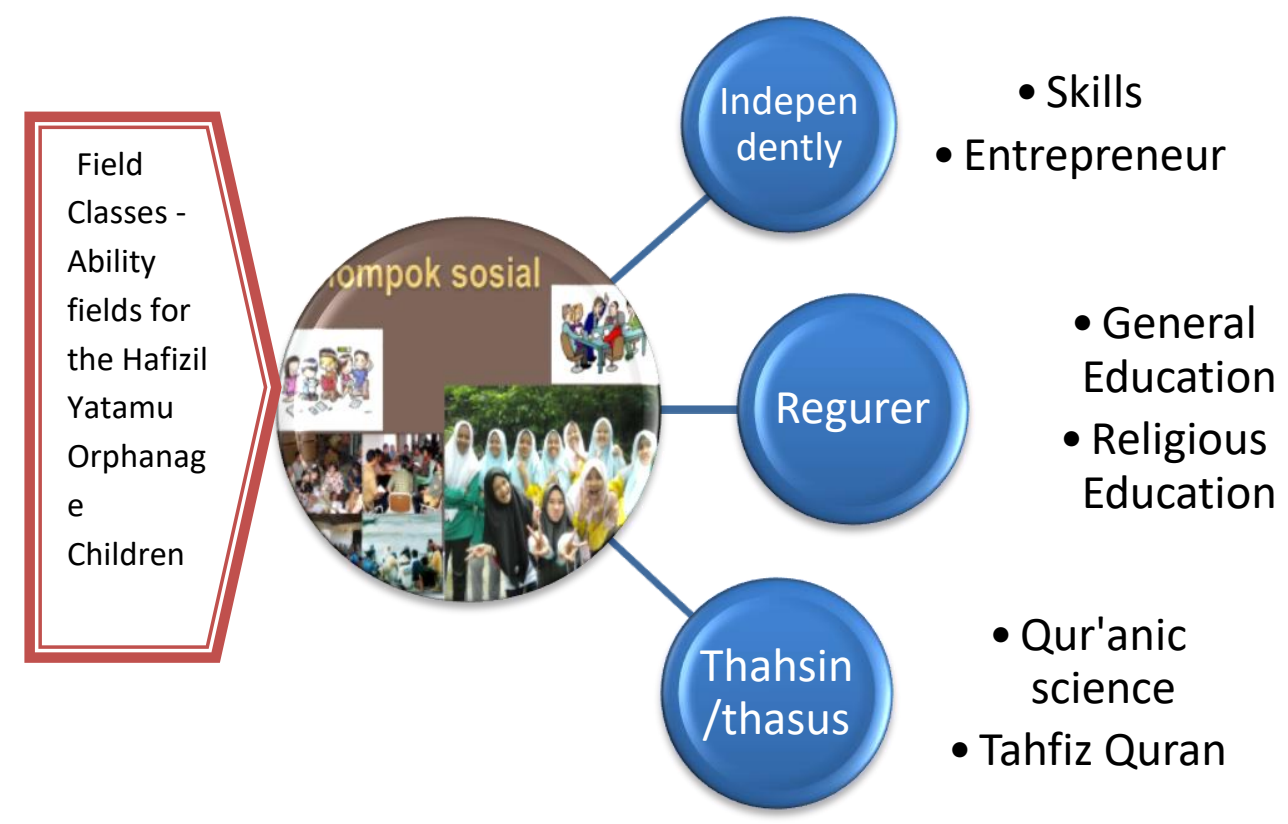

Figure 1. Class division of orphanage children Hafizil Yatamu Sabungan jae Padangsidimpuan

From the picture above explains, only three field classifications are set by the foundation for the hafizil yatamu sabungan jae padangsidimpuan orphanage to be educated and fostered by these orphans and dhuafa. The first class is an independent class, which is a class that has an entrepreneurial spirit. This independent class has several special learning methods that are applied in educating and fostering the entrepreneurial spirit of the orphanage and poor people. This method is what sharpens and sharpens his knowledge and entrepreneurial spirit so that he has high selfconfidence and is able to be independent in entrepreneurship. As for the methods, among others (Ahmad Yunus Hasibuan 2020).

The first learning method is to use the snowballing learning method (Munthe 2016), namely directly involving orphan and dhuafa orphanage children in the business process, thereby encouraging a sense of responsibility for the results of the business, then compromising different views in advancing these endeavors. This strategy familiarizes these orphans and poor people with finding answers to problems maximally. Involving orphan and dhuafa orphanages in a business is not determined by the orphanage. However, given the first choice to choose the business they like, then it will be used as entrepreneurial skills. 
As for the efforts involved in the orphanage children, among others, business of cultivating plants, trading in restaurants, selling credit business, livestock, repair shops and fisheries. After the children make their choice, the orphanage foundation will be directly involved in the business, starting from production, distribution to ideas. From this method, it will produce a skilled, mature and responsible entrepreneurial spirit.

After they are adults and have graduated from high school level, and are already skilled and mature in entrepreneurship, the orphanage foundation will provide 2 choices. The first option is out of the foundation to be self-sufficient. Because the foundation has completed its obligations in educating and fostering these orphans and poor people to adulthood. Second, stay under the foundation's territory to serve. Those who choose the first one to leave the foundation, then your Hafizil Yatamu orphanage will give up, because the orphanage can only educate and foster entrepreneurial spirit, not capital. However, those who chose the second option even though they were adults chose to stay at the orphanage or didn't get a job at all. Then it will be directed to various businesses owned by the orphanage foundation for service. because the Hafizil Yatamu Orphanage Foundation has quite a lot of businesses that it manages. These efforts are attached in the image below.

\section{Trading Business SUA}

- SUA Fishery

- SUA Thefarm

- SUA Printing

- SUA Mini Market

\section{Trading Business Hayat}

- Restaurant Hayat

- Cell Phone Hayat

- Workshop/Life Servis Hayat

- Flower Seeds Hayat

Figure 2. Trade businesses owned Hafizil Yatamu Orphanage Sabungan Jae Padangsidimpuan 


\section{Windari, Damri Batubara}

The Method of Empowerment Soul Entrepreneurship of Yatim and Dhuafa Orphanage Hafizil Yatamu Sabungan Jae

From the picture above, these businesses have various branches. 1. SUA Trading Business, has 4 branches. There are SUA fisheries, SUA livestock, SUA printing and SUA mini markets. 2. Hayat Trading Business, also has 4 branches. There is a living restaurant, a living cell phone, a workshop / life service and a living flower seedling.

Service in an orphanage does not mean that it does not have any work services. However, there are rules and regulations on the mechanism for providing services (honorariums) for those who work together with the foundation. Rules and conditions of service (work) with the Hafizil Yatamu orphanage foundation in the form of a mudharabah (profit sharing) contract. The profit sharing referred to here is the profit from the business which is shared excluding the capital. Meanwhile, the profit / capital is the absolute property of the foundation.

The profit sharing from the business is divided into 3 parts. The first part is for the business manager (workers), the second part is for the development of the orphanage foundation, the third part is for the owner of the orphanage foundation. As shown in the image below.

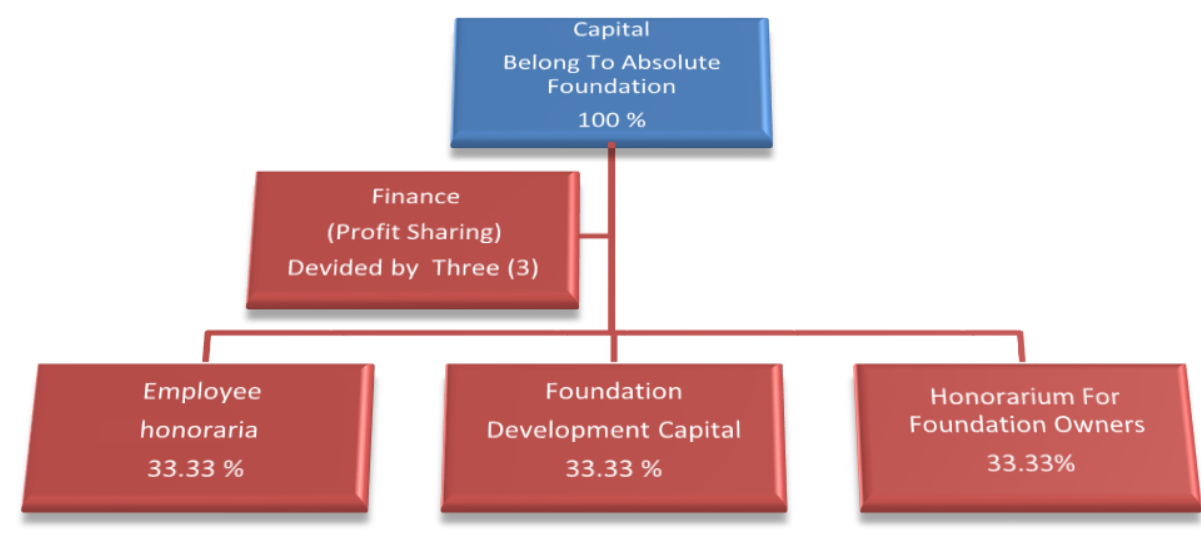

\section{Figure 3. Trading Business Profit Sharing Mechanism Hafizil Yatamu Orphanage Sabungan Jae Padangsidimpuan}

The second learning method carried out by the foundation in empowering the entrepreneurial spirit of the children of the Hafizil Yatamu orphanage Sabungan Jae Padangsidimpuan city. Doing the meet the guest learning method (Munthe 2016) namely, synergizing with the regeneration of the Hafizil Yatamu orphanage who have experienced entrepreneurship independently both nationally and internationally. By inviting them to become resource persons at the orphanage foundation, with the 
aim of arousing the confidence of the orphan and dhuafa children so that they are confident in facing future lives. Furthermore, the children of the orphanage depict various kinds of experiences of personal sources and teach good and correct entrepreneurial tricks according to the resource's theory and experience.

The third learning method applied by the foundation of the Hafizil Yatamu orphanage Sabungan Jae Padangsidimpuan town meeting (neighborhood association) (Munthe 2016) Namely, setting a special meeting every second day of Aidul Fitri for all alumni of orphanage and orphanage children and poor people at the orphanage location. The goal is mutual friendship as well as a place to share joy and happiness. This gathering has become a routine every year, so that from this routine new information about business and the world of work can be seen from alumni of orphanage cadre who are ready to become independent.

The fourth learning method applied by the Hafizil Yatamu Orphanage Foundation Sabungan Jae Padangsidimpuan in empowering the entrepreneurial spirit is the WhatsApp conference method (Munthe 2016), create a wide variety of social media tools. Like, Facebook, Twitter, Instagram and others. From this social media tool, friendship and information can run smoothly.

The second is the regular class, namely, the class devoted to education, general and religious.

This regular class is more inclined towards building moral character. With the hope that these children will be children who excel and get champions in various Olympics and others. The hope is that after completing primary, secondary and aliyah education, hopefully we can continue studying with scholarship capital. In this way, the future of the orphanage and the poor can be more secure.

The third class is the thahsin / thasus class, which is a special class for pen-tahfiz al-quran.

This Quranic tahfiz class is only reserved for those with strong memory power and high will. This class is fostered and guided by ustaz and ustazah who are professionals in the field of the Koran who are invited from outside the orphanage. The ustz and ustazah fees are funded by the foundation. It is hoped that this last class of orphanage and poor children will become good role models in society, become priests and become role models for the ummah in the future.

\section{Conclusion}

Based on the explanation of the head of the Hafizil Yatamu orphanage foundation, Sabungan Jae Padangsidimpuan city and the educators and coaches. There are 3 class areas that are educated and fostered in the social life of orphan and dhuafa children. The first is the independent class or also 


\section{Windari, Damri Batubara}

The Method of Empowerment Soul Entrepreneurship of Yatim and Dhuafa Orphanage Hafizil Yatamu Sabungan Jae

known as the entrepreneur class. Both regular classes or also known as education classes. The three classes of tahsin or also called tahfiz classes of the Quran. Of these 3 classes, what the researchers focused on was the method of empowering their independent class, also known as their entrepreneurial class. The method applied in empowering the entrepreneurial spirit of the orphans and the dhuafa of the Hafizil Yatamu orphanage is a learning method that is usually taught in schools. For example, the snowball learning method, meet the guest, town meeting, whatsapp conference. However, the difference is only in practice. In practice, this orphanage and dhuafa orphanage foundation directly involves the orphanage children to play an active role in entrepreneurship. Both in terms of production, distribution, management and others, resulting in a truly entrepreneurial spirit and a sense of full responsibility. When the children of the orphanage and poor people have grown up and have graduated from high school level, and are already skilled and mature in entrepreneurship, the orphanage foundation will provide 2 choices. The first option is out of the foundation to be selfsufficient. Second, stay under the foundation's territory to serve. For those who choose the second option, they still stay at the orphanage or haven't got a job at all. Then it will be directed to various businesses owned by the orphanage foundation for service. The profit sharing from the business is divided into 3 parts. The first part is for the business manager (workers), the second part is for the development of the orphanage foundation, the third part is for the owner of the orphanage foundation.

\section{References}

Ahmad Yunus Hasibuan. 2020. "Hasil Wawancara Ketua Yayasan Panti Asuhan Hafizil Yatamu Sabungan Jae Padangsidimpuan.”

Ana Toni Roby Candra Yudha. 2016. "Manajemen Pelayanan Pemberdayaan Anak Yatim Pada Lembaga Amil Zakat Yatim Mandiri di Surabaya.” Universitas Negeri Sunan Apel Surabaya Vol 2, No 1, Juni 2016.

George R Terry, Leslie W Rue. 2000. Dasar Dasar Manajemen. Cetakan ke 7. Jakarta: PT. Bumi Aksara.

kasdi, abdurrahman, dan moerdiyanto. 2017. pemberdayaan wakafproduktif berbasis wirausaha. Yogyakarta: Idea Press Yogyakarta.

Munthe, Bermawy. 2016. Strategi Mengajar Aktif Kreatif Inovatif. Edisi 2. Yogyakarta: Suka Press.

Sugiyoni. 2017. Metode Penelitian Administrasi Dilengkapi Dengan Metode R \& D. Cetakan 24. Bandung: Alfabeta.

Sugiyono. 2016. Metode Penelitian Kuantitatif, Kualitatif dan R\&D. Bandung: Alfabeta. 
Undang-Undang Republik Indonesia. 2002. Undang-undang Republik Indonesia Nomor 23 Tabun 2002 Tentang Perlindungan Anak. Jakarta.

Undang-undang Republik Indonesia, Republik. 1979. Undang-undang Republik Indonesia Nomor 4 Tabun 1979 Tentang Kesejabteraan Anak. Jakarta: Republik Indonesia.

Yuyus Suryana, Kartib Bayu. 2014. Kewirausahaan Pendekatan Karakteristik. Wirausahawan Sukses. Cetakan 4. Jakarta: Prenadamedia Group. 